\title{
Thoughts and Views on the Compilation of Monolingual Dictionaries in South Africa*
}

\author{
N.C.P. Golele, Xitsonga Language Research and Development Centre, Letaba, \\ Republic of South Africa (xitsolrdc@telkomsa.net)
}

\begin{abstract}
Developing and documenting the eleven official languages of South Africa on all levels of communication in order to fulfil all the roles and uses characteristic of truly official languages is a great challenge. To meet this need various bodies such as the National Lexicography Units have been established by the Pan South African Language Board (PanSALB). As far as dictionary compilation is concerned, acquaintance with the state-of-the-art developments in the theory and practice of lexicography is necessary.

The focus of the African languages should be directed onto the compilation of monolingual dictionaries. It is important that these monolingual dictionaries should be usable right from the start on a continuous basis. Continued attention should be given to enlarging the corpora and actual consultation of these corpora on the macro- and microstructural levels. The end-products should be of a high lexicographic standard, well-balanced in terms of lemma selection, length of the articles, maximum utilisation of available dictionary space etc. They should also be planned and compiled in such a way that the transition from paper dictionaries to electronic dictionaries could be easily and naturally accomplished. Advanced and continued training in the compilation of monolingual dictionaries should be presented.
\end{abstract}

Keywords: MONOLINGUAL DICTIONARIES, OFFICIAL LANGUAGES, DICTIONARY COMPILATION, CORPORA, NATIONAL LEXICOGRAPHY UNITS, TARGET USERS, DICTIONARY USE, DICTIONARY CULTURE, CORE TERMS

Opsomming: Gedagtes en beskouings oor die samestelling van eentalige woordeboeke in Suid-Afrika. Die ontwikkeling en dokumentering van die elf amptelike tale van Suid-Afrika op alle vlakke van kommunikasie om alle rolle en gebruike van werklik amptelike tale te vervul, is 'n groot uitdaging. Om in hierdie behoefte te voorsien, is liggame soos die Nasionale Leksikografie-eenhede deur die Pan Suid-Afrikaanse Taalraad (PanSAT) tot stand gebring. Wat woordeboeksamestelling betref, is bekendheid met die heel nuutste ontwikkelinge in die teorie en praktyk van die leksikografie noodsaaklik.

Die fokus van die Afrikatale moet op die samestelling van eentalige woordeboeke gerig wees. Dit is belangrik dat hierdie eentalige woordeboeke reg van die begin af op 'n deurlopende basis bruikbaar moet wees. Voortdurende aandag moet aan die uitbreiding van die korpusse en die

* This article is a slightly adapted version of a keynote address presented at the Tenth International Conference of the African Association for Lexicography, organised by the Sesiu sa Sesotho Lexicography Unit, University of the Free State, Bloemfontein, Republic of South Africa, 13-15 July 2005. 
werklike raadpleging van hierdie korpusse op makro- en mikrostrukturele vlak gegee word. Die eindprodukte moet van 'n hoë leksikografiese gehalte wees, goed gebalanseerd betreffende lemmakeuse, lengte van artikels, maksimum gebruik van beskikbare woordeboekruimte, e.s.m. Hulle moet ook op so 'n manier beplan en saamgestel word dat die oorgang van papierwoordeboeke na elektroniese woordeboeke maklik en natuurlik bewerkstellig kan word. Gevorderde en voortdurende opleiding in die samestelling van eentalige woordeboeke moet aangebied word.

Sleutelwoorde: EENTALIGE WOORDEBOEKE, AMPTELIKE TALE, WOORDEBOEKSAMESTELLING, KORPUSSE, NASIONALE LEKSIKOGRAFIE-EENHEDE, TEIKENGEBRUIKERS, WOORDEBOEKGEBRUIK, WOORDEBOEKKULTUUR, KERNTERME

A challenging new era has dawned on dictionary compilation in South Africa. In the dispensation prior to democracy in 1994, Afrikaans and English were privileged as the only two official languages. African languages were "official" in their respective homelands. In the new democratic South Africa, the African languages too enjoy official status throughout the country. Developing and documenting eleven official languages on all levels of communication in order to fulfil all roles and uses characteristic of truly official languages is a great challenge. In the field of lexicography, the Pan South African Language Board (PanSALB) has been tasked with the responsibility of establishing lexicography units for the eleven official languages to assist the processes of language preservation and development.

The Woordeboek van die Afrikaanse Taal (WAT) on which work started in 1926, can serve as an example of the slow and arduous process often characteristic of the production of a monolingual dictionary. Two decades later, in 1946, work had been produced on only the first ten letters of the alphabet. The manuscript was never published for reasons among which were that Afrikaans had not been properly standardized when the work began. A general lack of terminology was another factor. Furthermore there was uncertainty whether Afrikaans should move away from or closer to Dutch. Because of this, some Dutch words were included which never became part of Afrikaans. It is to obviate such problems that the Pan South African Language Board has established National Language Bodies, National Lexicography Units and Provincial Language Committees to expedite solutions to problems in areas such as lexicography, terminology, translation and interpreting, grammar and literature, to mention but a few challenges to be met. The African Association for Lexicography (AFRILEX) has to be commended for its role in providing guidance in the production of quality dictionaries.

On matters of standardization, the National Language Bodies met to authenticate the terminology lists of the Department of Arts and Culture, produced in various fields. There was also a meeting at the University of Pretoria to attend to matters of standardization of the African languages of South Africa. These activities point to the extent to which language matters receive attention in South Africa, and how lexicographic work could benefit. 
The National Lexicography Units are funded by Parliament through PanSALB with strict conditions attached, namely the production of publications which have actually to be exhibited to Parliament. This makes it clear that there is no time to waste as far as lexicography development is concerned. The units can therefore not afford the luxury of dialectics such as the prescriptive versus descriptive approach or issues of word versus stem traditions. There is also no time to leisurely and gradually develop and contrive sound lexicographic principles and practices. The units have to start producing immediately. This means that they must acquaint themselves with state-of-the-art knowledge in the theory and practice of lexicography. In the field of theoretical and practical lexicography, the combination of the contributions of foreign and local experts who show an interest in the development of lexicography in South Africa have to be embraced and optimally used.

The mandate of the National Lexicography Units is to produce comprehensive monolingual dictionaries and related products for the respective languages. Most units fruitfully utilized this opportunity to provide basic bridging dictionaries between the African languages and English. Some publishers are keen to assist with the publication of these dictionaries.

Needless to say, the value of bilingual dictionaries for mother-tongue speakers of African languages is not disregarded or disputed. If proper studies of users' requirements in the African languages reflect an urgent need for bilingual dictionaries, naturally such dictionaries should be compiled to satisfy these requirements. However, it is imperative that long-term preference be given to the compilation of comprehensive monolingual dictionaries for all the official languages, including Afrikaans and English. PanSALB, in terms of its vision and mission, should play an important part, and PanSALB and its structures, together with government departments and language associations and bodies, should collaborate to perform a decisive role in the compilation of such dictionaries. Even as bilingual dictionaries are produced, it is evident that they will need to be revised and updated from time to time in order to serve the lexicographic needs of the respective language communities. However, such revisions and updates should be secondary objectives not distracting attention from the main object, namely the compilation of monolingual dictionaries.

Monolingual dictionaries should be prepared in such a way that they are usable right from the start, and their production maintained. The situation of African languages makes it is impossible to wait decades for the completion of a dictionary. Therefore, monolingual dictionaries must be compiled as complete units, i.e. dictionaries comprising lemmas for all the letters of the alphabet, namely from A to $\mathrm{Z}$, continuously being increased in comprehensiveness and released as often as possible. Apart from serving the language communities, completed products also give the units a gratifying sense of accomplishment. Eventually such volumes could be extended to form a multi-volume dictionary. 
Continued attention has to be given to enlarging the corpora and actual consultation or querying of these corpora on the macro- and microstructural levels. On the macrostructural level, specific guidance should be given to lexicographers in respect of the compilation of lemma lists for these dictionaries. On the microstructural level, lexicographers should be continuously assisted to maximally utilize concordance lines for enhancing the quality of the articles to be compiled. The end products should be of a high lexicographic standard, well-balanced in terms of lemma selection, length of articles, maximum utilization of available dictionary space and other factors. These products should be planned and compiled in such a way that transition from paper dictionaries to electronic dictionaries, whenever the right time for this arrives, will be easily and naturally accomplished. This statement is made bearing in mind the less privileged circumstances in which some potential users find themselves. As in other spheres of life, the ideal aimed at has to be balanced with the realities of the circumstances of the less privileged. Advanced and continued training in the compilation of monolingual dictionaries should be presented by means of centralized and/or decentralized initiatives.

Frequency of release of products could depend also on strategies employed to reach desired goals. Experienced language practitioners in the community can be tasked with the function of providing definitions for lemmas for the monolingual dictionary. The task of the unit can therefore be reduced to that of formatting of the text. This strategy has the further advantage that more potential lemmas are generated by members of the community through the definitions. This contributes much to dictionary production. As cited by $\mathrm{Dr}$ P.A. Louw, formerly of the WAT, words or terms used in definitions should themselves be incorporated into the dictionary. This procedure allows for the broadening of the scope of the contribution to the lexicographic process.

Until recently the area of lexicography has been sadly neglected. It could be argued that the missionaries contributed to lexicographic development through the compilation of a number of bilingual dictionaries for the African languages. Although the value of their contribution is not disputed, it is true that these dictionaries were not compiled with the mother-tongue speakers in mind, but rather for the benefit of the missionaries to understand the relevant languages for their evangelization mission. Defunct departments of education of the past dispensation also produced some kind of dictionaries for the African languages in support of policies in which the intended users had no share or contribution. What is now required for the African languages in South Afri$\mathrm{ca}$ is a discontinuation of such Eurocentric approaches, and the adoption of a system where the lexicographic needs of the mother-tongue speakers of African languages take centre-stage.

Many challenges lie on the way of dictionary production in South Africa, such as staff recruitment and continuous training, motivation and guidance, retention of lexicographic skills, infrastructure, financial constraints and other factors. As far as staff composition is concerned, consideration should perhaps 
be given to an idea mooted by Dr M. Alberts of PanSALB at a workshop on terminology, that the lexicography units should incorporate terminologists in their staff structure to enhance their work.

At this stage of the development of the African languages, dictionary units should assist communities by placing a strong focus on the identification of the target users, their dictionary consultation skills, and their general needs. It should not be forgotten that modern dictionaries are compiled with a strong emphasis on the user perspective. In most cases, it amounts to the compilation of very practical, user-friendly dictionaries. In the end dictionaries are judged as good or bad by their target users.

Lemmas should be defined in such a way that users will find all the answers to the questions that cause them to consult the dictionary. Laufer (1992: 71) calls this objective knowing a word:

Knowing a word would ideally imply familiarities with all its properties ... When a person "knows" a word, he/she knows the following: the word's pronunciation, its spelling, its morphological components, if any, the words that are morphologically related to it, the word's syntactic behaviour in a sentence, the full range of the word's meaning, the appropriate situations for using the word, its collocational restrictions, its distribution and the relation between the word and other words within a lexical set ...

Lombard (1991: 166) identifies a number of defining criteria that would result in good definitions namely completeness, clarity, accuracy, consistency, independency, objectivity and neutrality.

Emphasis should also be on the situation of use - how and where the dictionaries are used in South Africa. The luxury of writing dictionaries only to be used in study rooms, libraries and well-equipped classrooms cannot be afforded. As already indicated, dictionary users should also be able to consult the dictionary even in less privileged circumstances.

The compilation of dictionaries in South Africa should in fact be viewed from two angles: improving the dictionaries and improving the users of such dictionaries. PanSALB, AFRILEX and the South African Broadcasting Corporation $(\mathrm{SABC})$ should, for instance, seriously consider incorporating presentations or broadcasts in the education service teaching dictionary use to children, and for that matter, to adults. The National Lexicography Units should also consider making the teaching of dictionary use an item on the agenda of their annual open days. It serves no purpose if dictionaries of good quality are compiled by the National Lexicography Units and also by private individuals but target users are not trained to use them. Issues of text production and text reception are important here.

In the Collins COBUILD English Language Dictionary, it is stated that "users expect more and more from their dictionaries, and in particular want to gain confidence in using a word by looking it up in a dictionary". The latter part of this remark underlines the responsibility of the lexicographer to supply enough 
productive (encoding) information to the user, and even more importantly, that this information should be on the level of the user.

Attention should also be given to the role of dictionaries in the creation of a dictionary culture. It could be a good idea to start with a small monolingual dictionary for primary school children and in doing so establish a dictionary tradition, then to compile follow-up dictionaries keeping pace with the development of this target group.

All core terms with which dictionary users as laypersons are confronted daily belong in a general dictionary. It helps to establish the authority of dictionaries as instruments of use, for example, by the inclusion of terms from the legal, medical and other professional fields.

In conclusion, aspects such as the following should be highlighted if the mandate of the National Lexicography Units in dictionary compilation is to be met: raising funds to supplement the state grant, commitment to and passion for the work, continued training of staff and use of available expertise, and collaboration with bodies supporting dictionary production.

\section{References}

Laufer, B. 1992. Corpus-based versus Lexicographer Examples in Comprehension and Production of New Words. Tommola, H. et al. (Eds.). 1992. EURALEX '92 Proceedings I-II: Papers Submitted to the 5th EURALEX International Congress on Lexicography in Tampere, Finland: 71-76. Tampere: University of Tampere.

Lombard, F.J. 1991. Die aard en aanbieding van die leksikografiese definisie. Lexikos 1: 158-182.

Sinclair, J. (Ed.). 1988. Collins COBUILD English Language Dictionary. London: HarperCollins. 